\title{
Community mapping and vegetational analysis of the mangrove forest in Calabanga, San Miguel Bay, Philippines
}

\author{
Agnes Zafe Faustino, ${ }^{1,}$, Helen Lonsamia Madela ${ }^{1}$, Richard Gavina Castor $^{1}$, Alvin \\ Paredes Muroda ${ }^{2}$, and Marian Nena Parato Chavez ${ }^{3}$ \\ ${ }^{1}$ Central Bicol State University of Agriculture-Calabanga Campus, Sta. Cruz, Calabanga, \\ Camarines Sur, Philippines \\ ${ }^{2}$ Ratay Elementary School, Ratay-Sta. Cruz, Calabanga, Camarines Sur, Philippines \\ ${ }^{3}$ Bagacay High School, Bagacay, Tinambac, Camarines Sur, Philippines
}

\begin{abstract}
Mangrove forests in Philippines have been noted for years to be continuously dwindling in terms of forest cover and diversity. The reasons behind these unfortunate events are the unabated illegal activities in the mangroves albeit the enforcement of laws and policies pertaining to its conservation and rehabilitation. For several decades, the Philippine government had been implementing programs and projects aiming to bring back the once pristine and productive mangrove areas through reforestation of denuded areas in the country. However, assessment is needed to evaluate whether these efforts have positively impacted coastal areas. This paper presents the current vegetational condition of selected reforested mangrove areas in Calabanga, San Miguel Bay, Philippines. Fifty-six (56) quadrats measuring $10 \times 10 \mathrm{~m}$ were established strategically in four (4) randomly selected rehabilitated mangrove sites. The overall results show that ten (10) mangrove species were recorded and Rhizophora apiculata and Rhizophora mucronata got the highest importance values of 111.59 and 105.96 respectively. This only shows that mono-specific mangrove species were considered during the rehabilitation of the areas set aside the environmental parameters affecting survival rate and the ecological diversity of the mangrove forest. A framework was developed to guide the local government in developing their sustainable mangrove management plan.
\end{abstract}

\section{Introduction}

Mangroves are trees or shrubs that thrive in a unique type of forest and can be found in coastal intertidal environments throughout the tropics [1] and they have substantial ecological significance and economic importance $[1,2,3,4,5,6]$ not only to the coastal dwellers but also to the entire communities.

The Philippine mangrove flora consists of 47 true mangroves and associated species belonging to 26 families [7]. While the mangrove fauna comprises shorebirds, some species of mammals (monkeys, rats, etc.) reptiles, mollusks, crustaceans, polychaetes, fishes, and

\footnotetext{
*Corresponding author: agnes.faustino@cbsua.edu.ph
} 
insects $[7,8]$. In the early 1900s, the Philippine mangroves were around 450,000 hectares $[8,9]$.

Mangroves have a multitude of uses and its existence is threatened due to activities like unregulated cutting, clearing and exploitation of the mangroves on a vast scale during the last century. In particular, cutting of mangroves for wood and for brackish water aquaculture, residential settlement, and infrastructure, have led to widespread decimation of forests in many countries, including the Philippines $[1,4,9,10,11,12,13,14,15,16]$. These brought the loss of $70 \%$ of its original mangrove forests [10, 15, 16, 17]. According to DENR 1995 statistics [18], these unabated activities have reduced the mangrove area up to 117,700 hectares.

To recover what have been lost, mangrove rehabilitation initiatives are being promoted by different organizations and institutions both in the private and public sectors, including donors or funding agencies throughout South and Southeast Asia, and increasingly in Africa, the Caribbean, and Latin America [19, 20, 21, 8, 22, 23, 1]. In this initiative and effort, the local communities are usually encouraged to be involved and engaged for the rehabilitation programs and projects to be successful by cultivating local stewardship of newly planted forests [1].

Rehabilitation programs and projects, however, halted because of the high mortality rate in the planted areas. The Philippines actually suffered this same fate during its massive rehabilitation efforts. [24, 15, 25, 26, 22]. As mentioned by Walters [16], even if rehabilitation efforts have succeeded, there is still no clear indication of whether local mangrove reforestation and management are likely to achieve desired economic and environmental conservation objectives, like preservation of forests and biodiversity, over a long-term period. Furthermore, Walters [16] explained that "one way to better understand this is to study local management systems that are already long-established".

In the San Miguel Bay, Philippines (1354.689'N, $\left.123^{\circ} 12.786^{\prime} \mathrm{E}\right)$ [27], massive rehabilitation efforts have been conducted decades ago. Most often, these rehabilitation activities were conducted by the Department of Environment and Natural Resources through the different local government units and sectoral groups. In Calabanga, one of the municipalities surrounding the Bay, both government and private sectors have involved in mangrove rehabilitation efforts. In 2009, Smart Communications through the Corporate Network for Disaster Response (CNDR) started the rehabilitation of 5 hectares mangrove area in Barangay Cagsao, Calabanga. Since then, more private corporations, individuals, academic institutions, non-government organizations, and government institutions provided financial and human resources to continue the initiatives. It has been ten years since the rehabilitation efforts have been done. This research provides information about the past and present status of mangroves vegetation and coastal dwellers utilization and management practices in the San Miguel Bay, Philippines.

\section{Methods}

This study was a part of a bigger research project of the Central Bicol State University of Agriculture (CBSUA) Calabanga Campus, Philippines. The initial salvo of the research was conducted in Calabanga and four (4) communities or barangays were selected as pilot survey areas. Four (4) barangays with large mangrove areas were chosen as study sites. These are Balongay, Cagsao, Salvacion Baybay, and Sibobo. Other barangays that have a large tract of Nypa fruticans were not included in pilot survey sites as there is a separate research study being undertaken by the team. The first phase of the research started in December 2017 until February 2018. On the other hand, the focus group discussions and key interviews were conducted in March 2019. 
Secondary data such as municipal and barangay profiles and mangrove reforestation related documents were collected. Also, maps from the National Mapping and Resource Information Administration (NAMRIA) were collected for community mapping exercises.

As the university advocates participatory research, key community personalities were involved in the process. An orientation on the basis of the research was discussed and they were taught on how to collect important data in the field. The participants were community locals who were designated by the municipality to protect and manage mangrove areas in their respective barangays. Participatory research was employed to impart social change and they play a role in the decisions and in crafting effective and efficient mangrove management programs and actions $[28,29,30,31]$.

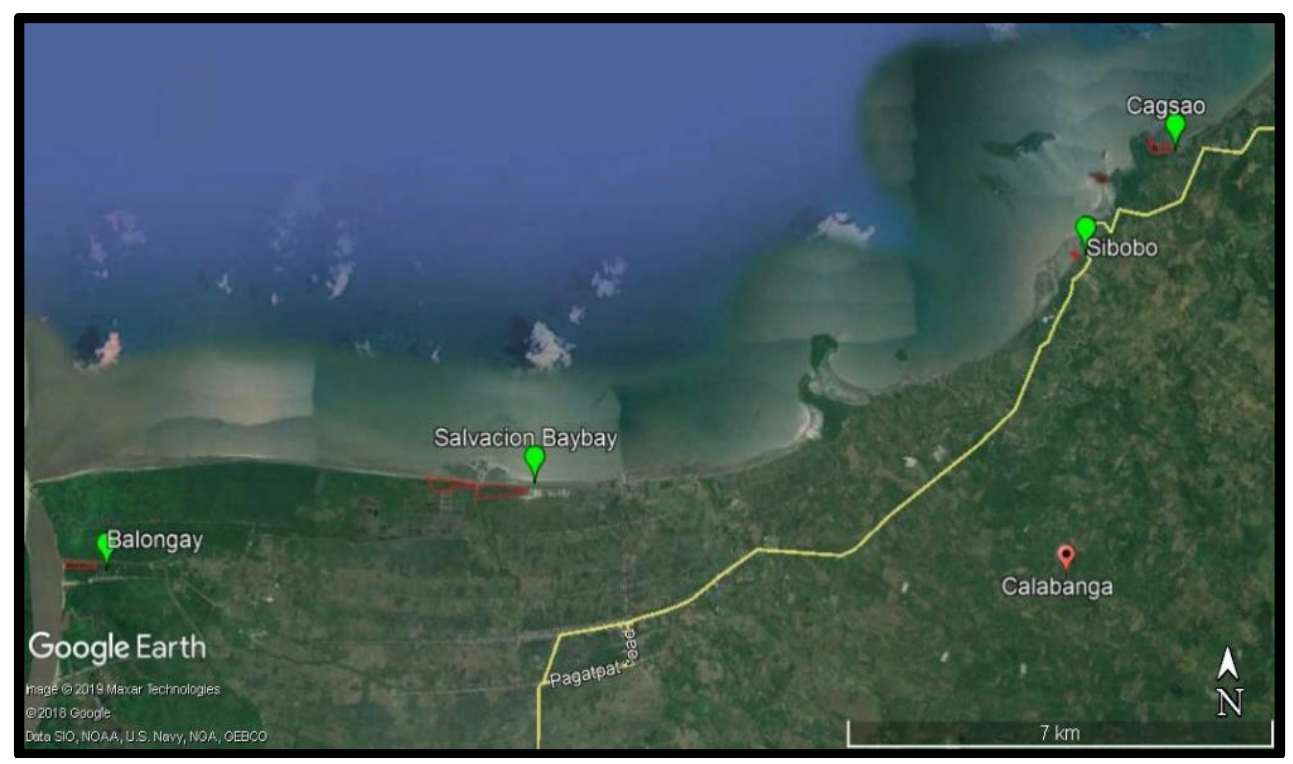

Fig. 1. The location of survey sites (green marks).

Fifty-six (56) quadrats or plots with a size of $10 \times 10 \mathrm{~m}[32,33]$ were established in the seaward, mid-ward and landward parts of the study sites for the vegetational analysis of mangrove forest. Inside the plots, each mangrove tree was identified using a field guide [34] while girth breast height $(\mathrm{GBH})$, which is approximately 1.3 meters above the ground, and height were measured and recorded [32]. Other physical observations inside and outside the plots were also noted to record any human activities that may be advantageous or disadvantageous to mangrove forests.

A community mapping was conducted to determine people's awareness of their mangrove areas. Focus group discussions (FGDs) and key informant interviews (KIs) were made for this particular activity. Participants were gatekeepers or barangay officials since they were the ones knowledgeable on the physical and environmental attributes and the history of their community. Also, information on utilization and management practices was gathered during the FGDs and KIs. After the community mapping, ground-truthing of the areas was conducted using a geographical positioning system (GPS).

The primary data that have been gathered were processed to determine the relative indices such as dominance, density, and frequency. These three relative indices were consolidated to get the importance value of mangrove species. Importance values refer to how important a species is in terms of the physical structure of a community [32]. 
Relative indices:

$$
\begin{aligned}
& \text { Relative Density }=\frac{\text { no.of individuals of a species }}{\text { total no.of individuals of all species }} \times 100 \\
& \text { Relative Frequency }=\frac{\text { frequency of a species }}{\text { Sum of frequency of all species }} \times 100 \\
& \text { Relative Dominance }=\frac{\text { Total basal area of a species }}{\text { Basal area of all species }} \times 100
\end{aligned}
$$

Simpson's index of diversity was used in determining species diversity. It is attributed to two major factors: (1) species richness, and (2) evenness. Species richness refers to the number of species in a particular area while species evenness compares the similarity of the population size of each of the species present. As species richness and evenness increase, so diversity increases. The value of $\boldsymbol{D}$ ranges between 0 and 1 . With this index, 1 represents infinite diversity and 0 , no diversity [35].

$$
D=1-\left(\frac{\sum n(n-1)}{N(N-1)}\right)
$$

Where:

$\mathrm{n}=$ the total number of organisms of a particular species

$\mathrm{N}=$ the total number of organisms of all species

The results of the FGDs and KIs on the communities' resource utilization and management practices served as corroborating statements substantiating the results of the analysis of the inventory of the flora of the mangrove forest.

A mangrove management framework based on the results of the research was initially developed to provide the local government unit with options and reference in crafting their own mangrove management plan.

\section{Results and Discussions}

\subsection{Vegetational Analysis}

The results of the vegetational analysis show that ten (10) mangrove species were identified inside the survey plots. These are, Avicennia alba ((bungalon; api-api), Avicennia marina (bungalon; api-api), Avicennia officinalis (bungalon; api-api), Aegiceras corniculatum (saging-saging; tinduk-tindukan), Aegiceras floridum (saging-saging; tinduk-tindukan), Bruguiera gymnorrhiza (pototan; busaing), Rhizophora apiculata (bakawan lalaki), Rhizophora mucronata (bakawan babae), Rhizophora stylosa (bakawan bato), and Sonneratia caseolaris (pedada).

Table 1 shows the average density per survey area. The results yielded that Barangay Cagsao has the highest species abundance of 2,144 (42.26\%) and it is followed by Barangay Salvacion Baybay with 1,750 (34.5\%). However, Barangay Sibobo recorded the lowest species abundance of 373 (7.35\%). In terms of average density per plot, Cagsao is the top rank with 97.45 per plot while Balongay moved slightly up with 89.56 leaving Salvacion Baybay behind with 87.5. Sibobo has the lowest density with the value of 74.6. 
Table 1. Average density per survey area in 2019.

\begin{tabular}{|c|c|c|c|c|c|c|}
\hline $\begin{array}{l}\text { Survey } \\
\text { Area }\end{array}$ & $\begin{array}{l}\text { Area } \\
\text { Covered } \\
\left(\mathrm{m}^{2}\right)\end{array}$ & $\begin{array}{l}\text { No. of } \\
\text { Survey } \\
\text { Plots }\end{array}$ & $\begin{array}{l}\text { Species } \\
\text { Abundance }\end{array}$ & $\begin{array}{l}\text { Ave. } \\
\text { Density Per } \\
\text { Plot }\end{array}$ & Ranking & Remarks \\
\hline Balongay & 38,900 & 9 & 806 & 89.56 & 2 & Riverine \\
\hline Cagsao & 60,400 & 22 & 2,144 & 97.45 & 1 & $\begin{array}{l}\text { Beachfront/ } \\
\text { reforested area }\end{array}$ \\
\hline $\begin{array}{l}\text { Salvacion } \\
\text { Baybay }\end{array}$ & 195,100 & 20 & 1,750 & 87.5 & 3 & $\begin{array}{l}\text { Beachfront/ } \\
\text { reforested area }\end{array}$ \\
\hline Sibobo & 6,400 & 5 & 373 & 74.6 & 4 & $\begin{array}{l}\text { Beachfront/ } \\
\text { reforested area }\end{array}$ \\
\hline Total & 300,800 & 56 & 5,073 & 90.60 & & \\
\hline
\end{tabular}

The relative indices (density, dominance, and frequency) characterize the physical attributes of the survey areas. For relative density, Rhizophora apiculata (RA) has the highest value of 41.36 and followed by Rhizophora mucronate (RM) with the value of 40.55 . The $3^{\text {rd }}$ is Sonneratia caseolaris (SC) with value of 6.7 and followed by Rhizophora stylosa (RS) with value of 4.59. The remaining mangrove species have insignificant relative density value.

For the relative dominance, RA and RM remain on top with values of 41.58 and 36.75 respectively. Then followed by SC (11.44) and RS (4.11). For the relative frequency, RA and RM exhibit the same results of 28.65. Whereas SC and RS got values of 15.79 and 11.11. Summing up the results, as expected, the importance value of RA is the highest at 111.59 while RM has 105.96. Following these two are SC (33.94) and RS (19.81).

Table 2. Relative indices of the survey area in 2018.

\begin{tabular}{llllll}
\hline Species & Code & $\begin{array}{l}\text { Rel. } \\
\text { Density }\end{array}$ & $\begin{array}{l}\text { Rel. } \\
\text { Dominance }\end{array}$ & $\begin{array}{l}\text { Rel. } \\
\text { Frequency }\end{array}$ & $\begin{array}{l}\text { Importance } \\
\text { Value }\end{array}$ \\
\hline $\begin{array}{l}\text { Avicennia alba } \\
\text { Avicennia marina }\end{array}$ & AA & 1.01 & 0.76 & 2.34 & 4.1 \\
$\begin{array}{l}\text { Avicennia officinalis } \\
\text { Aegiceras }\end{array}$ & AO & 3.61 & 2.34 & 7.6 & 13.55 \\
$\begin{array}{l}\text { corniculatum } \\
\text { Aegiceras floridum }\end{array}$ & AC & 0.2 & 0.01 & 0.58 & 0.31 \\
$\begin{array}{l}\text { Bruguiera } \\
\text { gymnorrhiza }\end{array}$ & AF & 0.1 & 0.09 & 0.58 & 0.78 \\
$\begin{array}{l}\text { Rhizophora } \\
\text { apiculata }\end{array}$ & $\mathrm{BG}$ & 0.16 & 0.43 & 0.58 & 1.17 \\
$\begin{array}{l}\text { Rhizophora } \\
\text { mucronata }\end{array}$ & $\mathrm{RA}$ & 41.36 & 41.58 & 28.65 & 111.59 \\
$\begin{array}{l}\text { Rhizophora stylosa } \\
\text { Sonneratia } \\
\text { caseolaris }\end{array}$ & $\mathrm{RM}$ & 40.55 & 36.75 & 28.65 & 105.96 \\
\hline Total & $\mathrm{RS}$ & 4.59 & 4.11 & 11.11 & 19.81 \\
\hline
\end{tabular}

Results of the Simpson's diversity index (SDI), shown in table 3, exhibit that Balongay has the highest diversity of .720. Then followed by Cagsao and Salvacion Baybay with values of .690 and .588 , respectively. On the other hand, Sibobo has the lowest SDI value of .482 . Overall, the survey areas got .65637 SDI. 
Table 3. Simpson's diversity index of the survey area in 2018

\begin{tabular}{lll}
\hline Survey Area & $\begin{array}{l}\text { Simpson's Diversity Index per } \\
\text { Survey Area }\end{array}$ & $\begin{array}{l}\text { Overall Simpson's } \\
\text { Diversity Index }\end{array}$ \\
\hline Balongay & .720 & .65637 \\
Cagsao & .690 & \\
Salvacion Baybay & .588 & \\
Sibobo & .482 & \\
\hline
\end{tabular}

Three (3) of the survey areas, i.e. Balongay, Cagsao, and Salvacion Baybay were identified as reforestation sites based on the Municipal Profile of Calabanga. It is prominent that Rhizophoraceae $s p$. is the most common and often used in replanting activities. For example, in Cagsao, as one of the biggest reforestation sites in the municipality and based on the results, RM and RA were found abundantly thriving in site 1. Aside from adopting monospecies replanting, the communities suggest that closed planting will bring a high survival rate. Those who were involved in replanting were paid per propagule thus, they tend to provide more planting supplies to avoid the tedious process of monitoring.

Nursery establishment was actually introduced by the Department of Environment and Natural Resources to the communities to prevent mono-species replanting. However, in Calabanga, it failed because of the communities' believed and valued more, both economically and environmentally, Rhizophoraceae $s p$. than the other species such as Sonneratiaceae sp. As suggested by Walters (2003), research in human ecology and the emerging field of forest history showed that human influences have long been pervasive in many forests. Humans believe that intensive rehabilitation efforts must be done to recover what has been lost, introducing various technologies to fast track the initiatives but forgetting that nature has its own way of recovery.

\subsection{Community Mapping}

Fig 2 shows the comparative maps of Balongay in 2006 against the most recent map produced using Google Earth Pro in 2019. Changes that have been noted were the absence of concrete barrier in 2006 where the portion of mangrove forest was cleared construction of infrastructure. On the other hand, as mentioned by the community members, mangroves in the particular area are denser now compared to 2006 because of the rampant cutting of mangroves for fuelwood.
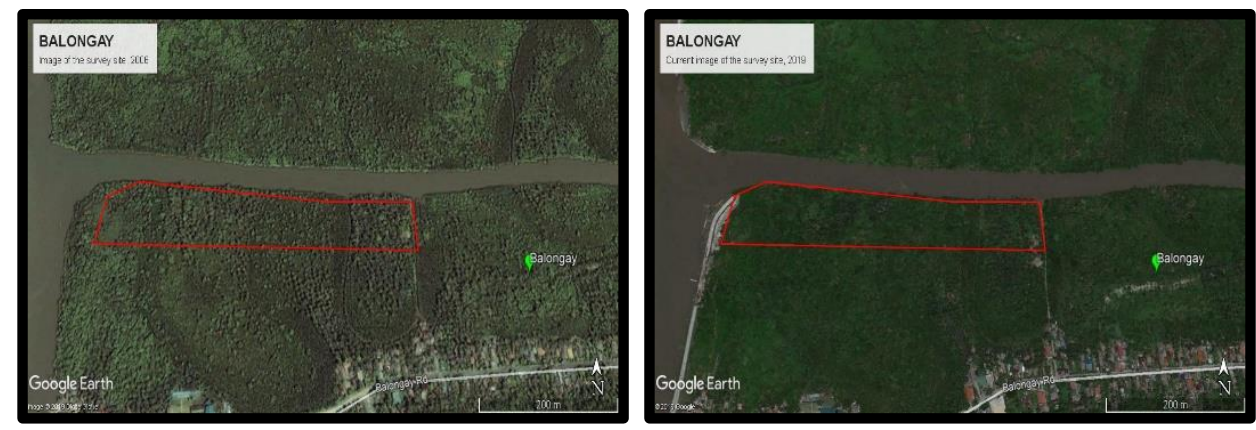

Fig. 2. Comparative maps of Balongay mangrove forest (2006 and 2019).

In Barangay Cagsao (Fig 3), the mangrove forest that is claimed present today is missing in 2006. Although there is a thin line of mangrove in the upper left survey site in 2006, however, the large tract of mangroves in other areas was not seen in the map. In the 2019 map, however, the green lush mangroves are visible. 

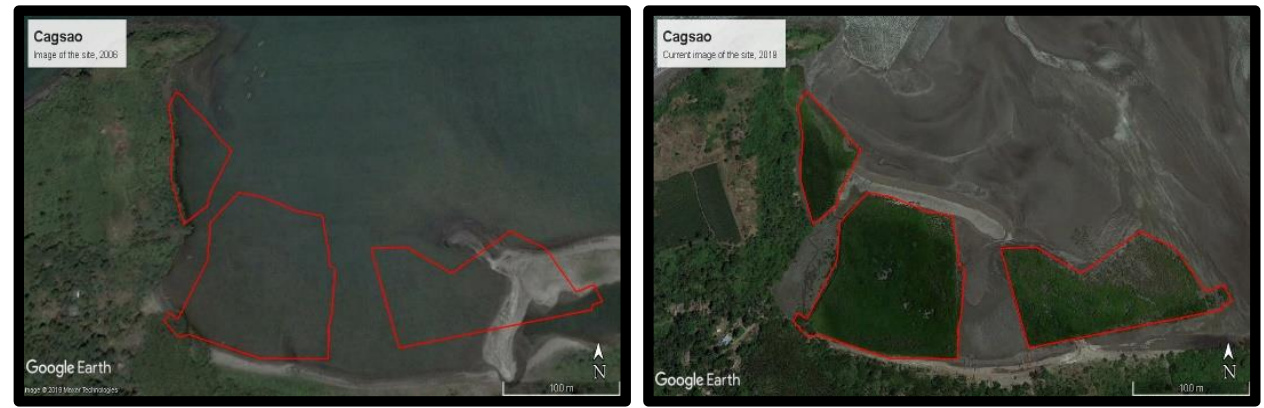

Fig. 3. Comparative maps of Cagsao mangrove forest (2006 and 2019).
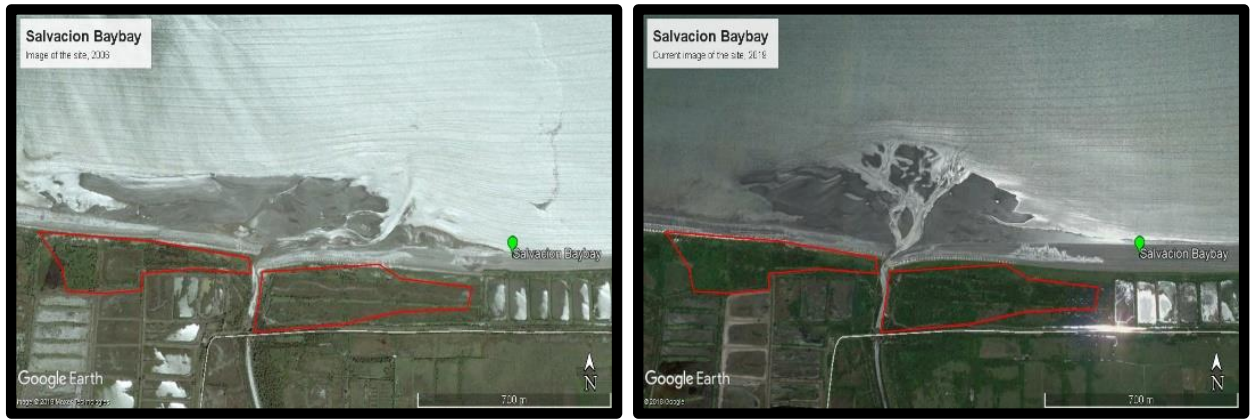

Fig. 4. Comparative maps of Salvacion Baybay mangrove forest (2006 and 2019).

Salvacion Baybay (Fig 4) is one of the areas that have been rehabilitated by the Fisheries and Aquatic Resource Management Council (FARMC), a council composed of the different fisherfolk organizations. With them are the local government of Calabanga, and the Bureau of Fisheries and Aquatic Resources Regional Office 5 (BFAR RO5). Looking at the comparative maps, only a sparse mangrove forest was present in 2006 due to the concerted efforts of the FARMC, local government, and BFAR RO5. The sparse mangrove forest is home to Rhizophoraceae sp.

Lastly, in Barangay Sibobo (Fig 5), the survey area is missing in 2011. Instead, a large area of mudflat is visible. Currently, the survey area is home to Rhizphoraceae $s p$ and other mangroves species.
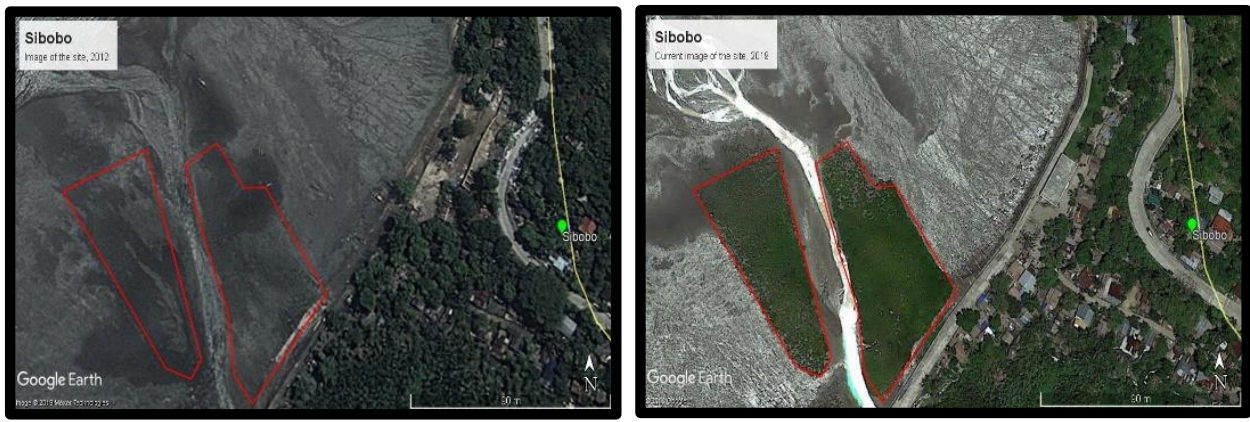

Fig. 5. Comparative maps of Sibobo mangrove forest (2011 and 2019)

The maps that have been presented here only shows that the mangrove forest in Calabanga was heavily abused and exploited either by the locals or migrants. Also, the "missing forests" in Cagsao and Sibobo can be attributed to the ever-changing landscape of the coastal area of Calabanga. 


\subsection{Utilization and Management Practices}

Mangroves in Calabanga have been subjected to abuse and massive exploitation for several decades. It has been noted that these abuses are results of communities' belief that mangroves are free and a finite resource.

The utilization of mangroves is a household activity where family members were assigned with specific tasks depending on age and gender. Males play a major role while their wives and children only assist them. However, for those single parents especially single parent and old women living alone or only with their young children, they assume the male-related tasks that are more physically demanding such as collecting twigs and fallen branches for firewood and fishing near the mangroves. Charcoal making according to them has stopped and was never encouraged due to the strict implementation of Municipal Fisheries Ordinance 200304-A that prohibits communities from exploiting the mangrove forests in Calabanga. What they collect from the mangroves are resources that are not abusive to the entire forests.

In 2009, as shared by the mangrove forest guard, the Corporate Network for Disaster Response (CNDR) was commissioned by the Smart Telecommunications to conduct mangrove rehabilitation activities through mangrove planting. In coordination with the Local Government Unit of Calabanga, rehabilitation sites were chosen and community people were engaged in the activities. Meetings, orientations, and consultations were conducted to prepare the municipality and barangays in the activity to be undertaken. As Rhizophoraceae $s p$ propagules could be easily collected in mangrove forests, this particular species was considered and used in replanting activities. Those involved in the replanting were paid Php. 25 per propagule. Distance between one propagule to another was never considered except that high survival rate must be met. Based on records, a total of 23 hectares were replanted with Rhizopharaceae sp mangroves in six (6) barangays. Table 4 shows the details of the mangrove rehabilitation initiatives in Calabanga [36].

Table 4. Mangrove forest rehabilitation initiatives in Calabanga

\begin{tabular}{lllll}
\hline \multicolumn{1}{c}{ Barangay } & $\begin{array}{l}\text { Area planted } \\
\text { (has) }\end{array}$ & Potential area & $\begin{array}{l}\text { No. of } \\
\text { propagules (pcs) }\end{array}$ & Species \\
\hline Cagsao & 6.0 & 10 & 223,500 & Rhizophoraceae $s p$. \\
Sibobo & 2.0 & 5 & 50,000 & Rhizophoraceae $s p$. \\
Punta-Tarawal & 1.5 & 10 & 30,000 & Rhizophoraceae $s p$. \\
Balatasan & 1.5 & 10 & 30,000 & Rhizophoraceae $s p$. \\
Sabang & 6.0 & 10 & 123,000 & Rhizophoraceae $s$. \\
Bonot & 2.0 & 10 & 50,000 & Rhizophoraceae $s p$. \\
\hline \multicolumn{1}{c}{ Total } & 23 & 55 & 506,500 & \\
\hline
\end{tabular}

After the phase-out of CNDR's mangrove rehabilitation program, the local government unit of Calabanga took over and continued the effort. To date, academic institutions such as Ateneo de Naga University, CBSUS-Calabanga, and other schools are engaging more in the protection and management of the mangrove resources.

\subsection{The sustainable mangrove management framework}

To ascertain the successful implementation of the protection and management of mangrove forests, a participatory management framework was crafted that can serve as a guide in the development of sustainable mangrove conservation and management plan. Fig 6 shows three (3) major players: the academe, the local government of Calabanga and the national government agencies (NGAs). As a catalyst of change, these major players may consider working together to attain the development that the communities needed to save the remaining mangrove forests in Calabanga. The academe such as the CBSUA-Calabanga can provide research services to extend this study that can give more in-depth information in the 
crafting of sustainable conservation and management plan. Also, as educators, the academe can assist in capacitating the coastal dwellers to increase their knowledge, skills, and attitude in mangrove conservation programs and projects that could improve their living conditions.

The local government of Calabanga, as the gatekeeper of the municipality, can provide capitalization to coastal dwellers for sustainable livelihood endeavors that would divert them from over-using mangrove resources. Furthermore, strict implementation of the MFO-200304-A must be continuously enforced for the communities to be more disciplined and courageous in protecting and managing mangrove forests.

The national government agencies (NGAs) such as the Department of Environment and Natural Resources (DENR) and the Bureau of Fisheries and Aquatic Resources (BFAR) can provide technical assistance to the communities via law enforcement. Close monitoring by these agencies is vital for the successful implementation of programs and projects related to mangrove conservation and management.

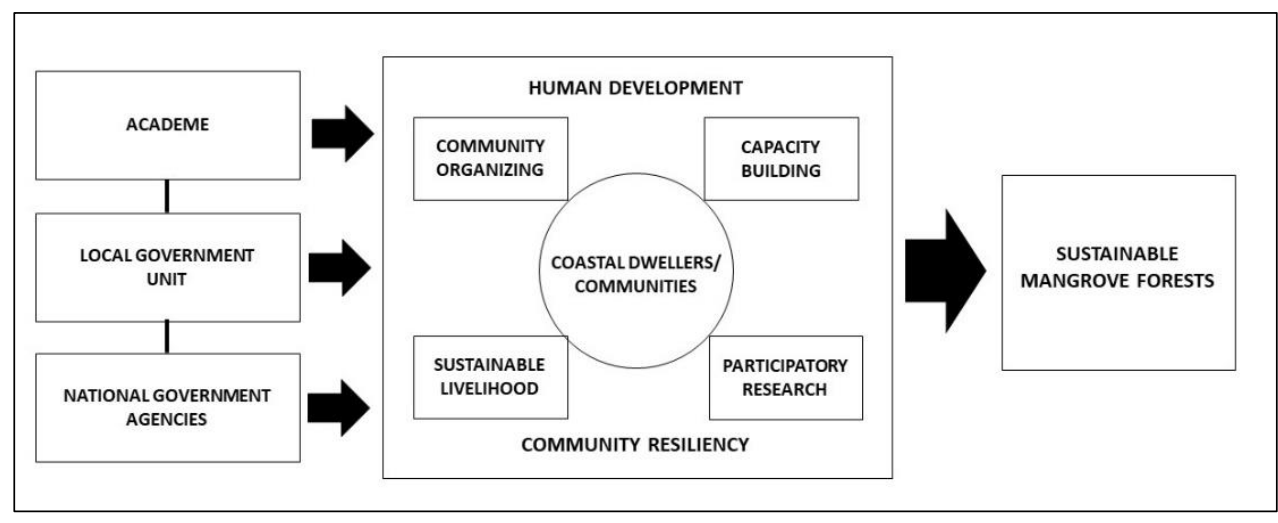

Fig. 6. Sustainable mangrove management framework in 2019

Community organizing, capacity building, participatory research, and sustainable livelihood are the major strategies that can be employed to increase the knowledge, skills and attitude of the coastal dwellers. Community organizing is a process of empowering [37] the marginalized sectors to become more aware of their sector's issues and concerns, more engaged in the discussions and be more articulate in finding and providing solutions. With community organizing, the coastal dwellers can have the freedom to evaluate their current condition, discuss among themselves the source of their problems and objectively find solutions to issues and concerns.

After organizing the communities, providing capacity building activities through trainings, seminars and workshops are beneficial to the communities. As we prepare them to engage more in the field of mangrove conservation and management, building their knowledge, skills, and attitude on the subject must be ensured. Participatory research is also crucial in human development and community resiliency. The participation of the communities in the entire process of community researches can be seen as multiple functions. During the learning process of research, the community members increase their level of awareness on the status of mangrove forests.

Diverting coastal dwellers from harvesting products from the mangroves can be difficult or impossible. However, by providing technical know-how and capitalization to engage in sustainable livelihood programs and projects, it is possible and attainable. Financial literacy is the key to more successful and sustainable livelihood ventures. With these strategies, the framework tells us that human development and community resiliency towards sustainable mangrove forests can be attained. 
The present study suggests although massive rehabilitation has been made in the mangrove forests of the municipality, future studies on the rehabilitation sites such as faunal survey to determine its impact on fisheries production should be conducted. Mangrove rehabilitation is not only to plant and recover the forest but the most important thing is applying science-based protocols for mangrove rehabilitation and management.

\section{References:}

1. B. B. Walters. People and mangroves in the Philippines: Fifty years of coastal environmental change Environmental Conservation 30 (2): 293-303 (C) 2003 Foundation for Environmental Conservation (2003)

2. B. Christensen. Management and Utilization of Mangroves in Asia and the Pacific. FAO Environment Paper 3. Rome, Italy: Food and Agriculture Organization of the United Nations: 160 pp. (1982)

3. FAO. Mangrove Forest Management Guidelines. FAO Forestry Paper117.Rome, Italy: Food and Agriculture Organization of the United Nations: 319 pp (1994)

4. L. S. Hamilton, J. A. Dixon, \& G. O. Miller. Mangrove forests: an undervalued resource of the land and of the sea. In: Ocean Yearbook 8, ed. E.M. Borgese, N. Ginsburg \& J.R. Morgan, pp. 254-288. Chicago, USA: University of Chicago Press (1989)

5. L. D. Lacerda, ed. Conservation and Sustainable Utilization of Mangrove Forests in Latin America and African Regions (Part 1: Latin America). Mangrove Ecosystem Technical Reports 2, International Society for Mangrove Ecosystems and International Tropical Timber Organization: 272 pp. (1993)

6. W. Macnae. A general account of the fauna and flora of mangrove swamps and forests in the Indo-West-Pacific Region. Advances in Marine Biology 6: 73-270. McCoy (1968)

7. E. E. Melana and H.H. Gonzales. Field guide to the identification of some mangrove plant species in the Philippines. Ecosystems Research and Development Service, Department of Environment and Natural Resources, region 7, Banilad, mandaue, Cebu City, Philippines 29p. +8p. appendices (1996)

8. D. M. Melana, J. Atchue III, C. E. Yao, R. Edwards, E. E. Melana, and H. I. Gonzales. Mangrove Management Handbook, Department of Environment and Natural Resources, Manila, Philippines through the Coastal Resources Management Project, Cebu City, Philippines. 96pp. (2000)

9. W. H. Brown. and A. F. Fischer. Philippine mangrove swamps. Bulletin 17, Bureau of Forestry, Department of Agriculture and Natural Resources, Manila, the Philippines (1918)

10. S. R. Baconguis, D. M. Cabahug, and S. N. Alonzo-Pasicolon. Identification and inventory of Philippine forested-wetland resource. Forest Ecology and Management 33/34: 21-44 (1990)

11. B. R. Dewalt, P. Vergne, and M. Hardin. Shrimp aquaculture development and the environment: people, mangroves and fisheries on the Gulf of Fonseca, Honduras. World Development 24: 1193-1208. (1996)

12. M. A. Eusebio, F. O. Tesoro, and D. M. Cabahug. Environmental impact of timber harvesting on mangrove ecosystem in the Philippines. In National Mangrove Committee (ed.), Mangroves of Asia and the Pacific: Status and Management, Natural Resources Management Center, Ministry of Natural Resources, Quezon City, Philippines, pp. 337354 (1986) 
13. S. K. Meltzoff, \& E. LiPuma. The social and political economy of coastal zone management: shrimp mariculture in Ecuador. Coastal Zone Management Journal 14: 349-380. (1986)

14. J. H. Primavera. A critical review of shrimp pond culture in the Philippines. Reviews in Fisheries Science 1: 151-201. (1993)

15. J. H. Primavera. Mangroves and brackish water pond culture in the Philippines. Hydrobiologia 295: 303-309. (1995)

16. B. B. Walters. Local Management of Mangrove Forests in the Philippines: Successful Conservation or Efficient Resource Exploitation? Human Ecology, Vol. 32, No. 2, April 2004 (C2004) Department of Geography, Mount Allison University, Sackville, NB, CANADA E4L 1A7 (2004)

17. S. E. Siddall, J. A. Atchue III, and R. L. Murray Jr. Mariculture development in mangroves: A case study of the Philippines, Ecuador and Panama. In Clark, J. R. (ed.), Coastal Resources Management: Development Case Studies. Renewable Resources Information Series, Coastal Management Publication No. 3. Prepared for the National Park Service, US Department of Interior, and the US Agency for International Development. Research Planning Institute, Columbia, South Carolina. (1985)

18. DENR Statistics. Environment and Natural Resources Atlas of the Philippines. Published by the Environment Center of the Philippines Foundation. 1998. Manila, Philippines (1995)

19. J. G. Kairo. Community participatory forestry for the rehabilitation of deforested mangrove areas in Kenya. Paper presented at the International Tropical Timber Organization's International Mangrove Workshop, Cartagena, Colombia, February 1922. (2002)

20. U. L. Kaly and G. P. Jones. Mangrove restoration: A potential tool for coastal management in tropical developing countries. Ambio 27: 656-661. (1998)

21. R. R. Lewis. Creation and restoration of coastal plain wetlands in Florida. In J. A. Kusler and M. E. Kentula.(eds.), Wetland Creation and Restoration: The Status of the Science, Island Press, Washington, DC, pp. 73-101. (1990)

22. P. Saenger, and N. A. Siddiqi. Land from the sea: The mangrove afforestation program in Bangladesh. Ocean and Coastal Management 20: 23-39. (1993)

23. A. Thorhaug. Restoration of mangroves and seagrasses-Economic benefits for fisheries and mariculture. In Berger, J. J. (ed.), Environmental Restoration: Science and Strategies for Restoring the Earth, Island Press, Washington, DC, pp. 265-281 (1990)

24. H. P. Calumpong. Status of mangrove resources in the Philippines. In Wilkinson, C., Sudara, S., and Ming, C.L. (eds.), Proceedings of the Third ASEAN-Australia Symposium on Living Coastal Resources, Bangkok, Thailand, May 16-20, 1994, Vol. 1. Australian Agency for International Development (AUSAID) and Australian Institute of Marine Science, Townsville, Australia, pp. 215-229. (1994)

25. R. S. Pomeroy, R. B. Pollnac, C. D. Predo, and B. M. Katon. Impact Evaluation of Community-Based Coastal Resource Management Projects in the Philippines. International Center for Living Aquatic Resources Management (ICLARM), Makati City, Philippines. (1996)

26. J. H. Primavera, and R. F. Agbayani. Comparative strategies in community-based mangrove rehabilitation programs in the Philippines. Paper presented at the ECOTONEV: Community Participation in Conservation, Sustainable Use and Rehabilitation of Mangroves in Southeast Asia, Ho Chi Minh City, Vietnam, January 812, 1996. (1996) 
27. Google Earth Pro

28. D. J. Greenwood, \& M. Levin. Introduction to action research: Social research for social change. Thousand Oaks, CA: Sage. (1998)

29. T. Koch, P. Selim, \& D. Kralik. Enhancing lives through the development of a community-based participatory action research program. Journal of Clinical Nursing, 11, 109-117. (2002)

30. C. MacDonald. Understanding participatory action research: A qualitative research methodology option Canadian Journal of Action Research 13, Issue 2, 2012, pages 3450. (2012)

31. J. McNiff, \& J. Whitehead. All you need to know about action research. Thousand Oaks, CA: Sage. (2006)

32. AIMS. Survey manual for tropical marine resources, $2^{\text {nd }}$ edition. Edited by S. English, C. Wilkinson and V. Baker. pages 180-184 (1997)

33. WAVES. Mangrove Forest Inventory and estimation of Carbon Storage and Sedimentation in Pagbilao. Philippine Statistics Authority (2017)

34. J. H. Primavera. Field Guide to Philippine Mangroves. Philippine Tropical Forest Conservation Foundation, Inc. and Zoological Society of London (2009)

35. Barcelona Field Study Center. Simpson's Diversity Index. https://geographyfieldwork.com/Simpson'sDiversityIndex.htm

36. Calabanga Municipal Fisheries Profile, (2017)

37. CCEF. Introduction to the Establishment of a Community-Based Marine Sanctuary. http://www.oneocean.org/download/20010129/marine_sanctuary/main_english_ver.pd $\underline{\mathrm{f}}$

38. J. T. Curtis. The Vegetation of Wisconsin. An Ordination of Plant Communities. University of Wisconsin Press, Madison. 657pp. (1959)

39. Municipal Fisheries Ordinance No. 2003-04-A, Article 9 Section 58-61

40. J. H. Primavera, J. P. Savaria, B. E. Bajoyo, J. D. Coching, D. J. Curnick, R. L. Golbeque, A. T. Guzman, J. Q. Henderin, R. V. Joven, R. A. Loma, and H. J. Koldeway. Manual on Community-Based mangrove Rehabilitation: Mangrove Manual Series No. 1. First edition. London, UK: ZSL, viii +240p (2012) 